\title{
Mbembe, A. (2017). CRÍtica dA RAZ̃̃o Negra. LisboA: Antígona.
}

\author{
Vítor de Sousa
}

Crítica da razão Negra [Critique of Black reason], by Achille Mbembe, is not a story about ideas, or an exercise in historical sociology, despite making use of history "to put forth a style of critical reflection about the world of our time" (p. 21). Straightaway in the work's Introduction, Achille Mbembe lets the reader know that it's included in a process that's at a preliminary stage in connection with the urgency to open up the problem of racial policy, racism and colonialism to critical thinking, declassifying the status quo hinged on predeterminations and stereotypes tending to bring "comfort" to the predominant logic. In other words, the need to put behind the notion of absolute truth, which, as early as 1997, Stuart Hall called attention. And this is what this book is about, that it comprises an underscored theoretical clipping, where the author expounds on the concept of "black," on the evolution of European thinking that was behind it, with regard to affixing the stamp on those that are subordinated (which he calls "black development" of the world) and regarding stratagems intended to overshadow the matter itself. This book deems it urgent to mentally decolonize Europe in order to fight the phenomenon of global racism forged by rampant capitalism, where potentially everyone could be the new "blacks".

The work includes the trilogy that starts with Sortir de la grande nuit (2010), where the author looks into the problem of decolonization from a decolonial perspective, and ends with Politiques de l'inimitié (2017), where he fosters a cross-sectional dialogue with thinkers from different quarters who dealt with the colonial issue and how it relates to imperialism, capitalism and racism. Translated (to Portuguese) by Marta Lança, it can be viewed as a parody of Kant's Critique of pure reason, where it seeks to show the structural link between the concepts of modernity and coloniality, and which expounds on what it says is the "blackification" of the world and the generalization of that condition, going beyond biological and sociological boundaries of the racialized "other", where the "black" would be disowned in the world.

Within this framework, the author, who is a historian, a philosopher, a Political Science professor, and an academic reference in the study of post-colonialism and currently one of the most renowned African intellectuals, recalls the weight of eurocentrism, which

always tended to address identity not in terms of mutual belonging (copresence) to a single world, but, rather, how they relate to one another, the emergence of the being and of their manifestation in their first being or even in their own mirror. (p.10) 
By contrast, we need to understand whether "black" and race have meant the same thing for the imaginaries of European societies, as a result of that logic "of autofiction, self-contemplation and, above all, enclosure" (p. 10).

Upon observing primary assertions regarding race that have been developed mostly from the $17^{\text {th }}$ century, and whose resulting terminology he dubs as that of a "delirium" arising from modernity, Mbembe remarks that the concepts of slave and black are blurred, while recalling that the "black" goes from man-merchandise (black slave trafficking) to man-metal (mining in Africa) and, then, to man-currency (as the product of exchange in capitalism) (p. 300). He also looks at the basic manifestations of the concept of "black", starting off by that where we see "when nothing is seen, when we don't understand anything and, especially, when we don't want to understand anything"; likewise, that where "nobody (...) would wish to be a black or, in practice, to be treated as such"; and, finally, "simultaneously working as an ordinary, material and phantasmagorical category", where race has been, throughout the previous centuries, behind countless catastrophes, "and which has been the cause of untold devastations and incalculable crimes and carnages" (p. 11).

Achille Mbembe refers to a "black development of the world", where all of subordinate Humanity risks becoming black, and where the inequalities on which the entire process is hinged runs the risk of being quickly disseminated. He explains that all this is the result of the violence of capitalism, namely Atlantic slave trafficking and the colonization in the $19^{\text {th }}$ and $20^{\text {th }}$ centuries, whose logic is quickly disseminating and arriving in Europe. In the current crisis context, he expands the concept of "black" to a universal condition to which everyone is subject due to the fact that neoliberalism, in the wake of new exploitation models characterizing it, looks to everyone as blacks, with the subsequent idea of related subjection. This does not diverge much from the racist logic experienced, namely in sectors of Portuguese society, which even today dubs as "black" he who is subject, for example, to much harder work usual. As it turns out, this is a remnant of the colonial social dynamic that Mbembe himself seeks to tear down.

This is not separate from the notion of the decline of Europe and its re-focus in the world, with the subsequent loss of its importance. According to Mbembe, Europe's sunset is announced "even if the Euro-American world has not become aware of, despite wanting to know (or to pretend to know) about, the black man", which now leads many countries to assert a "raceless racism". In order to enhance the practice of discrimination, where race becomes conceptually unthinkable, he explains that this caused "culture and religion to take the place of "biology'". This, in turn, leads him to state that republican universalism is blind in relation to race: "non-Whites are encapsulated in their supposed origins, while fully racialized categories continue to proliferate, which mostly feed islamophobia on a daily basis". This is why there is no question in his mind that the moment has come arrived in order to found something absolutely new, "while Europe goes astray, caught by the disease of not knowing where the world is at" (p. 20).

The impact for racism and for the notion of race within the subordination of Europe, can be explained by history. Mbembe concluded that the systematic risks to which 
black slaves were exposed during the first capitalism forms the basis for constant dynamics of subordination. Thus, it's no wonder that the author's common thread in relation to this problem hinges on a framework of economic clipping, and so we cannot separate subjecting the "black man" from capitalist exploitation. Racism would, therefore, have been developed to legitimize capitalism, through oppression and exploitation, as racial assumptions were required for this to survive.

He maintains that the concepts of race and racism are constantly renewed, regardless of the players' side of the fence, thus simplifying a complex ideological process. Mbembe points out that reducing human beings to a biological dynamic (such as skin color) is nothing more than mere fiction, while emphasizing that Europe and America in particular "take the black man and race and make two versions of a single figure: encoded madness" (p. 11). The construction of the "black man" identity thus included not only establishing one's own name, but also its internalization and, finally, subverting the concept. The author does not merely unleash his criticism on ideological currents that legitimize colonialism, as he also extends them to "africanist" movements, where

proclaiming difference is just a moment on a broader project - of a coming world, of a world preceding us, where destiny is universal, a world free from the weight of race and resentment and from the desire for revenge summoned by any situation of racism. (p. 306)

Transversal to the books' six chapters ("The issue of race", p. 25; "The pit of hallucination", p. 75; "Difference and self-determination", p. 139; "The little secret", p. 179; "Réquiem for the slave", p. 223; and "The subject's clinic", p. 255) are the author's references to Frantz Fanon, of whom he admits to being a fan, namely in the last chapter. Proof of that is his comment regarding the author of Black skin, white masks, concerning the political concept of colonial era racist violence, quoting him quite simply: "Fanon says violence is not just an integral part of colonial oppression. Such a system's duration over time, established with violence, is, he explains, 'a function of maintaining violence'" (p. 183), notwithstanding the colonial discourse comprising an underdeveloped contour articulated around the stereotypes of otherness. Mbembe refers that, if there's anything we owe Fanon, it's precisely the notion whereby, in any human being, there is "something indomitable, truly intangible, that domination (...) cannot achieve or do away with, or contain, or repress, at least totally" (p. 285). This is how he points out that there is no relation to himself that does not go by way of a relation with the Other:

the other is nothing more than the difference and similarity combined. What we will need to imagine is a policy where the human being is essentially a policy of what is similar, but within a context where, truth be told, what we share together are the differences. And, paradoxically, these are what we need to set in common. (p. 297)

Setting differences in common goes by way of repair and of "a broad concept of justice and responsibility" (p. 297). 
This notion is reasserted and developed in the works "Epilogue" entitled "There is but one world" (p. 299), and where Mbembe highlights a few paths to a future seeking to be "free from the weight of race and resentment" (p. 306). This is a process only achievable through justice, restitution and repair: "to build this world that is ours, it will be necessary to restore, to those who have gone through processes abstraction and objectification in history, that part of humanity of which they have been robbed", as the concept of "reparation", as an economic category, "hearkens to the process of bringing together parts that were amputated, to repairing bonds that were broken". That's why he maintains that "restitution" and "repair" ("because history has left wounds and scars e cicatrizes (...) that hinder forming a community", p. 305) are at the center of the very construction of a common awareness of the world, which will entail the "fulfillment of a universal justice" (p. 304). To such end, the author suggests the need for Europe to be mentally decolonized, within a logic where "construction of what is common [is] inseparable from reinventing the community" (p. 305). And, as he reminds us, this is not a linear process, as we need to take into account countless scars "[of] those who experienced colonial domination or who, at a given point in history, were robbed of their humanity, recovery of this part of humanity often goes by way of proclaiming the difference" (p. 306).

Originally published in 2013 (the first edition appeared in Portugal the following year), the work is highly up-to-date, and so it's no wonder it was republished in 2017. At a time when, at a global scale, concepts recently regarded as true are being called into question, it makes sense to summon a few high-profile controversies that recently put forth in the media, starting in the summer of 2017. This is the case with events that took place in Charlottesville, Virginia (U.S.), with the toppling of statues honoring symbols of the Confederate States, highlighting the rift between those maintaining they pay tribute to the U.S. Civil War and should not be removed, and those in favor of bringing them down, saying they are racist symbols extolling slavery. Such situations have had repercussion, even in Portugal. To this end, we simply need to hearken back to the Portuguese president's visit to Gorée, Senegal (2017), where he was criticized for not having issued an apology for Portugal's role in the slave trade there, a place known for having served as a former outpost for Atlantic slave trafficking routes. Likewise, the dedication of the statue of Father António Vieira (at largo Trindade Coelho, in Lisbon, in 2017), where the author and prelate is depicted in the company of three Indian children, which critics claim to denote colonial paternalism, but which, by contract, warranted a show of support from a far-right group defending alleged national values. Or Lisbon City Council's idea of creating a Museum of the Discoveries, a name that does not garner consensus, as it prompted various public stances among those maintaining its alleged nationalist contours and those underpinning that it needs to display the darker side of the Discoveries (such as slavery, lootings and conquest-related violence). Or, in 2018, with the CDS political party reviving an old proposal to compensate those dispossessed when they lived in the former Portuguese colonies, while seeking the greatest possible consensus regarding a topic which that party still regards as an open sore resulting from the decolonization process. 
This is the visible face of the struggle between history and the memory which, despite being two different things, tend to be mistaken in this kind of activisms. Paul Ricoeur establishes a link between memory and history, as he feels that historical study stages the memory's work. Still, this remains a contradictory process, as this fosters selection, transforming previous experiences so that they are adjusted to new uses, while engaging in forgetfulness, which will be the only way to give way to the present (Ricoeur, 2000). According to Irene Flunser Pimentel, as memory is placed into the event, becoming contemporary to that which it attempts to convey and is based on experience from a past that left scars on its players, history, in the form of knowledge, distances itself while seeking to draw some sense from the past:

while history establishes a distance from its reference object, to the extent where it is more distant, more objectivizing, more impersonal in its relation to the past, it can play an equitable and truthful role, in order to mitigate the exclusivity and faithfulness of particular memories. (Pimentel, 2013, n.p.)

José Neves remarks that the historiographic report is doomed to use words from the past and from today, as

the problem does not lie in the circumstance of a historian giving a speech on subjects from a given period, making use of names from other periods included in an anachronism; the problem arises when the historian does not give details (...) or discusses such an intertextual relation. (Neves, 2016, p. 14)

It is, after all, as Moisés de Lemos Martins (2014) points out, the purpose of Lusophony, proof of the existence of a rift between mistakes need to be deconstructed among players from a history of the relation between a colonial 'me' and a colonizing 'other'. This is why engaging in mental decolonization is urgent, as advocated by Mbembe, in order to overcome such mistakes and to settle resentments, feelings of superiority and/or inferiority, as well as ideological imaginations. What underpins relational diversity among the parties, counteracting the homogenization brought about by globalization, where, the more identical people are, the swifter the circulation of capital, goods and information, but which will result in less criticism expressed by citizens and where the end product will be monolithic.

Translation: Traduções Técnicas do Minho, Lda.

\section{REFERENCES}

Hall, S. (1997). The centrality of culture: notes on the cultural revolutions of out time. In K. Thomson (Eds.), Media and culture regulation (pp. 208-238). United Kingdom: The Open University.

Martins, M. L. (2014). Língua portuguesa, globalização e lusofonia. In N. Bastos (Ed.), Língua portuguesa e lusofonia (pp.15-33). São Paulo: EDUC - IP-PUC. 
Neves, J. (2016). Os sujeitos da História. In J. Neves (Ed.), Quem faz a História? Ensaios sobre o Portugal contemporâneo (pp. 9-16). Lisboa: Tinta da China.

Pimentel, I. F. (2013, 20 de fevereiro). Será que a História nos pode fornecer algo de preventivo e "anular o destino"? [Blog post]. Retrieved from http://irenepimentel.blogspot.com/2013/02/

Ricoeur, P. (2000). La memóire, l'histoire, l'oubli. Paris: Éditions du Seuil.

\section{BiOgRAPHICAL NOTE}

Holder of a Ph.D in Communication Sciences (Intercultural Communication), from the University of Minho, in 2015, Vítor de Sousa authored the thesis Da 'portugalidade' à lusofonia; he holds a master's degree (specialization in Media Education) and a B.A. (specialization in Information and Journalism) in the same field. His areas of research include issues surrounding identity, Cultural Studies, Media Education and Journalism theories. He is a researcher at CECS, where he is part of the Group of Cultural Studies, a member of Sopcom, ECREA and the Association of Friends of the Penafiel City Library. He was awarded the 2016 Mário Quartim Graça Scientific Prize, given to the best thesis completed in the last three years in the field of Social and Human Sciences, in Portugal and Latin America. He was a journalist (1986-1997) and press secretary (1997-2005).

ORCID: https://orcid.org/oooo-0002-6051-0980

Email: vitordesousa@gmail.com

Address: CECS-Centro de Estudos de Comunicação e Sociedade, ICS-Instituto de Ciências Sociais, Universidade do Minho, Campus de Gualtar, 4710-057 Braga

* Submitted: 15.05 .2018

* Accepted: 29.06.2018 